\title{
Trilodothyronine induces lipid oxidation and mitochondrial biogenesis in rat Harderian gland
}

\author{
A Santillo, L Burrone, S Falvo, R Senese, A Lanni and G Chieffi Baccari \\ Dipartimento di Scienze e Tecnologie Ambientali, Biologiche e Farmaceutiche, Seconda Università degli \\ Studi di Napoli, via Vivaldi, 43, 81100 Caserta, Italy
}

Correspondence should be addressed to A Santillo Email alessandra.santillo@unina2.it

\begin{abstract}
The rat Harderian gland (HG) is an orbital gland producing a copious lipid secretion. Recent studies indicate that its secretory activity is regulated by thyroid hormones. In this study, we found that both isoforms of the thyroid hormone receptor ( $\operatorname{Tr} \alpha$ (Thra) and $\operatorname{Tr} \beta$ (Thrb)) are expressed in rat HGs. Although Thra is expressed at a higher level, only Thrb is regulated by triiodothyronine $\left(T_{3}\right)$. Because $T_{3}$ induces an increase in lipid metabolism in rat HGs, we investigated the effects of an animal's thyroid state on the expression levels of carnitine palmitoyltransferase-1A (Cpt1a) and carnitine palmitoyltransferase-1B (Cpt1b) and acyl-CoA oxidase (Acox1) (rate-limiting enzymes in mitochondrial and peroxisomal fatty acid oxidation respectively), as well as on the mitochondrial compartment, thereby correlating mitochondrial activity and biogenesis with morphological analysis. We found that hypothyroidism decreased the expression of Cpt1b and Acox 1 mRNA, whereas the administration of $\mathrm{T}_{3}$ to hypothyroid rats increased transcript levels. Respiratory parameters and catalase protein levels provided further evidence that $\mathrm{T}_{3}$ modulates mitochondrial and peroxisomal activities. Furthermore, in hypothyroid rat HGs, the mitochondrial number and their total area decreased with respect to the controls, whereas the average area of the individual mitochondrion did not change. However, the average area of the individual mitochondrion was reduced by $\sim 50 \%$ in hypothyroid $\mathrm{T}_{3}$-treated $\mathrm{HGs}$, and the mitochondrial number and the total area of the mitochondrial compartment increased. The mitochondrial morphometric data correlated well with the molecular results. Indeed, hypothyroid status did not modify the expression of mitochondrial biogenesis genes such as Ppargc1a, Nrf1 and Tfam, whereas $\mathrm{T}_{3}$ treatment increased the expression level of these genes.
\end{abstract}

\section{Key Words}

- Harderian gland

- triiodothyronine

- lipid oxidation

- mitochondrial biogenesis

\section{Introduction}

The Harderian gland (HG) is a large tubuloalveolar gland present in the orbit of most terrestrial vertebrates (see Chieffi et al. 1996 for review). In the rat, HG excretes large amounts of characteristic lipids, and it also produces porphyrins and melatonin (see Chieffi et al. 1996 for review).
Although the function of HG is uncertain, its function is closely related to lipid secretion. Lipids act as lubricants and are most likely solvents for pheromones and other biologically active substances (Lin \& Nadakavukaren 1981, Sakai 1981). Excretory lipids also act in thermoregulation

Published by Bioscientifica Ltd 
of gerbils (Thiessen 1988) and blind mole rats (Shanas \& Terkel 1996).

HG activity is influenced by both exogenous factors (light and temperature) (Minucci et al. 1990, Buzzell et al. 1994, Santillo et al. 2011a) and endogenous factors (hormones). Androgens seem to be involved in the control of HG secretory activity (d'Istria et al. 1991, Chieffi Baccari et al. 1993, Santillo et al. 2011a), as well sexual dimorphism in the golden hamster gland (McMasters \& Hoffman 1984, Santillo et al. 2008, Coto-Montes et al. 2009). Furthermore, significant evidence suggests that this gland is a target for thyroid hormones (TH). Nuclear receptors for triiodothyronine $\left(T_{3}\right)$ have been observed in the HG of the golden hamster (Vilchis \& Perez-Pelacios 1989). TH injections lead to an increase in porphyrin content in hamster HG, an effect that is reversed under conditions of TH deficiency (Hoffman et al. 1989, Buzzell $\&$ Menendez-Pelaez 1992). More recently, we demonstrated that hypothyroidism provoked a reduction in lipid secretion as well as apoptosis and autophagic phenomena in rat HG (Monteforte et al. 2008), whereas $\mathrm{T}_{3}$ administration induced an increase in lipid secretion, hypertrophy of the mitochondrial compartment and an increase in the expression of uncoupling protein 3 (Chieffi Baccari et al. 2004, Santillo et al. 2011b), which is a mitochondrial protein with a function that is related to lipid metabolism (Cioffi et al. 2009). The presence of type II thyroxine $5^{\prime}$-deiodinase $\left(5^{\prime} \mathrm{D}\right)$, an enzyme that converts thyroxine to $\mathrm{T}_{3}$, in both rat and hamster HGs provided further evidence that this gland is a target for TH (Delgado et al. 1988, Osuna et al. 1990). Following thyroidectomy, the activity of $5^{\prime} \mathrm{D}$ in rat $\mathrm{HG}$ increases and exhibits a marked circadian rhythm (Guerrero et al. 1987).

Because the physiological effects of $\mathrm{TH}$ are exerted at the level of transcription through interaction with specific TH receptors (TR $\alpha$ (THRA) and TR $\beta$ (THRB)), in this study, we investigated $\mathrm{TH}$ receptor expression in rat $\mathrm{HG}$, as well as their regulation by $\mathrm{T}_{3}$. Further, as $\mathrm{T}_{3}$ induced an increase in lipid metabolism in rat $\mathrm{HG}$, we decided to investigate the effects of $\mathrm{T}_{3}$ on the expression levels of carnitine palmitoyltransferase-1 (Cpt1a and Cpt1b) and acyl-CoA oxidase (AOX (Acox1)), which are rate-limiting enzymes in mitochondrial and peroxisomal fatty acid oxidation respectively. Next, because $T_{3}$ stimulates fat oxidation by acting at the mitochondrial and peroxisomal levels, we studied the effect of an animal's thyroid state on the mitochondria, correlating mitochondrial activity and biogenesis with morphological analysis, and on the peroxisomes, assessing catalase protein levels.

\section{Materials and methods}

\section{Animals and $T_{3}$ determination}

Male Wistar rats (Rattus norvegicus albinus), weighing 300$350 \mathrm{~g}$, were maintained under regulated conditions of temperature $\left(28^{\circ} \mathrm{C}\right)$ and light $(12 \mathrm{~h}$ light: $12 \mathrm{~h}$ darkness cycles). The rats received commercial food pellets (Mil-Rat, Morini, Italy) and water and were allowed to feed and drink ad libitum. To induce hypothyroidism, rats $(n=30)$ received i.p. injections of 6-n-propylthiouracil (PTU; $1 \mathrm{mg} / 100 \mathrm{~g}$ body weight) daily for 4 consecutive weeks. In addition, the rats received an i.p. injection of iopanoic acid (IOPA; $6 \mathrm{mg} / 100 \mathrm{~g}$ body weight) (Lanni et al. 1996) once a week. PTU blocks thyroidal hormone synthesis via inhibition of thyroid peroxidase activity, and it is also a strong inhibitor of type I 5'-D-deiodinase activity (Oppenheimer et al. 1972, Leonard \& Visser 1986). IOPA inhibits all three types of deiodenase enzymes. Although the effect of IOPA is strong on type II and III, it is comparatively weak on type I (Kaplan \& Utiger 1978, St Germain 1994). At the end of this treatment, 15 hypothyroid rats were killed and the remaining 15 hypothyroid rats received daily injections for 2 weeks of $15 \mu \mathrm{g} \mathrm{T} / 100 \mathrm{~g}$ body weight (Sigma-Aldrich Corp.). Control rats $(n=15)$ received saline injections. Before killing, the animals were anaesthetised with an i.p. injection of chloral hydrate $(40 \mathrm{mg} / 100 \mathrm{~g}$ body weight) and were decapitated. Trunk blood was collected, and the serum was separated and stored at $-20^{\circ} \mathrm{C}$ for subsequent $\mathrm{T}_{3}$ determination. The HGs (weighing 100-150 mg) were removed through dissection, weighed and rapidly immersed in liquid nitrogen for molecular analysis. Pieces of gland were quickly immersed in fixative for electron microscopy, as described below. Total $\mathrm{T}_{3}$ levels were determined in $50 \mu \mathrm{l}$ samples of serum using reagents and protocols supplied by BD Biosciences (Franklin Lakes, NJ, USA). All experiments were performed in accordance with local and national guidelines governing animal experiments.

\section{RNA isolation and quantitative real-time PCR}

Total RNA was extracted from rat HGs $(n=5$, for each experimental group) using a standard TRIzol protocol (Invitrogen Life Technologies) and later treated for $30 \mathrm{~min}$ at $37^{\circ} \mathrm{C}$ with DNase I (10 U/sample) (Amersham Bioscience) to eliminate any genomic DNA contamination. Total RNA purity was determined by spectrophotometry at $260 / 280 \mathrm{~nm}$, and RNA integrity was determined by electrophoresis on a denaturing formaldehyde agarose gel. One microgram of total RNA was reverse-transcribed using the SuperScriptTM First-Strand Synthesis System kit (code 11904-018, Invitrogen Life Technologies).

Published by Bioscientifica Ltd. 
Specific primer sets were designed for quantitative realtime RT-PCR (qRT-PCR) using Primer 3 (http://frodo.wi. mit.edu/primer3). The sequences of the primers used are reported in Table 1. As a reference gene, we used the ribosomal protein S12 (Rps12) oligonucleotide primers (Table 1). Each reaction contained $12.5 \mu \mathrm{l}$ iQSYBR green Supermix (code 170-8882, Bio-Rad Laboratories), $2 \mu \mathrm{l}$ cDNA template and $6 \mathrm{nmol} / \mathrm{l}$ primers. The expression of individual gene targets was analysed using the MyiQ2 Real-time PCR machine (Bio-Rad Laboratories). The thermocycle programme contained a step at $95^{\circ} \mathrm{C}$ (3 min), 35 cycles at $95^{\circ} \mathrm{C}(10 \mathrm{~s})$ and a step with either 58 or $60^{\circ} \mathrm{C}$ for $30 \mathrm{~s}\left(58^{\circ} \mathrm{C}\right.$ for Thra, Thrb and Rps 12 and $60^{\circ} \mathrm{C}$ for Cpt1a, Cpt1b, Acox, Pprgc1a, Nrf1 and mitochondrial transcription factor-A (Tfam)). Samples were subsequently subjected to a denaturation protocol consisting of 71 cycles that started at $55^{\circ} \mathrm{C}$ and later increased $1{ }^{\circ} \mathrm{C}$ every $10 \mathrm{~s}$ to generate a dissociation curve to confirm the presence of a single amplicon. For every qRT-PCR assay, samples were run in duplicate along with a negative template control (RNase-free water instead of cDNA template). The relative standard curve method was used to interpolate relative mRNA abundance of target and reference genes within each sample. The standard curves were generated using equal parts of cDNA from each treatment. Reaction efficiencies were determined by the iQ5 Optical System Software (version 2.1, Bio-Rad Laboratories) using the slope of the standard curves, and for all the genes, the efficiencies were $90-110 \%$ with $R^{2} \geq 0.990$. The mRNA levels of the reference gene Rps12 did not change in the various experimental groups (data not shown). Therefore, transcript level data were normalised to Rps12.

\section{Preparation of mitochondria and peroxisomes}

Mitochondria and peroxisomes were isolated by homogenisation of rat HGs ( $n=5$, for each experimental group) in an isolation medium consisting of $220 \mathrm{mM}$ mannitol, $70 \mathrm{mM}$ sucrose, $20 \mathrm{mM}$ Tris- $\mathrm{HCl}, 1 \mathrm{mM}$ EDTA, $5 \mathrm{mM}$ EGTA and $5 \mathrm{mM} \mathrm{MgCl}_{2}$, pH 7.4, supplemented with the following protease inhibitors: $1 \mathrm{mM}$ benzamidine, $4 \mu \mathrm{g} / \mathrm{ml}$ aprotinin, $1 \mu \mathrm{g} / \mathrm{ml}$ pepstatin, $2 \mu \mathrm{g} / \mathrm{ml}$ leupeptin, $5 \mu \mathrm{g} / \mathrm{ml}$ bestatin, $50 \mu \mathrm{g} / \mathrm{ml} \mathrm{N}$-tosyl-L-phenylalanine-chloromethyl ketone and $0.1 \mathrm{mM}$ phenylmethylsulfonylfluoride. After homogenisation in this medium, samples were centrifuged at $700 \boldsymbol{g}$ for $10 \mathrm{~min}$. The supernatant was collected and transferred into new tubes for subsequent centrifugation at $3000 \mathrm{~g}$ for $10 \mathrm{~min}$. The obtained mitochondrial pellet was washed twice, then resuspended in a minimal volume of isolation medium and used for the determination of respiratory parameters. The resulting supernatant fraction was subjected to centrifugation at $10000 \boldsymbol{g}$ for $10 \mathrm{~min}$. The peroxisomal pellet was washed twice and resuspended in a minimal volume of isolation medium and used for the catalase expression analysis.

\section{Respiratory parameters determination}

Mitochondrial respiration was determined polarographically at $30^{\circ} \mathrm{C}$ in a respiratory medium consisting of $80 \mathrm{mM} \mathrm{KCl}, 50 \mathrm{mM}$ HEPES, $5 \mathrm{mM}$ PBS, $10 \mathrm{nM}$ sodium succinate, $3.75 \mu \mathrm{M}$ rotenone and $1 \%$ free fatty acid BSA, $\mathrm{pH}$ 7.0. State 3 respiration was initiated by the addition of $300 \mu \mathrm{M}$ ADP, and the method described by Estabrook (1967) was used to calculate the rates of state 4 and 3 respiration and the respiratory control ratio. The protein concentration was determined by the method of Hartree (1972).

\section{Ultrastructure and morphometric analyses}

For electron microscopy, pieces of HGs $\left(3 \mathrm{~mm}^{3}\right)$ were promptly immersed and left for $3 \mathrm{~h}$ in Karnovsky's fixative in cacodylate buffer (pH 7.4) and were postfixed for $2 \mathrm{~h}$ in

Table 1 Primers for real-time PCR

\begin{tabular}{ll} 
Gene & Forward primer $\left(5^{\prime}-3^{\prime}\right)$ \\
\cline { 1 - 1 } $\begin{array}{l}\text { Thra } \\
\text { Thrb }\end{array}$ & GCTTCTTTCGCCGTACAATC \\
Ppargc1a & GTCAACAGTTGGCATTGAAC \\
Nrf1 & CAACAGGGAAGAAACGGAAA \\
Tfam & CTGATGGCCATTACATGTGG \\
Cpt1a & CGGAGCAGGGATACAGAGAG \\
Cpt1b & ATCGAACGTGCTGCTTTCTT \\
Acox & CTGATGAAATACGCCCAGGT \\
Rps12 & AAATCGATCGAGAGGGGAAG
\end{tabular}

Reverse primer $\left(5^{\prime}-3^{\prime}\right)$
ACTGATTCCGGGTGATCTTG
AGGTCCGTCACCTTCATCAG
GTGTGAGGAGGGTCATCGTT
GTGGCTCTGAGTTTCCGAAG
AAAGCCCGGAAGGTTCTTAG
TCAAAGCATCTTCCATGCAG
ATTTGCCGTAGAGGCTGAGA
GGTCCCATACGTCAGCTTGT
CTTGGCCTGAGATTCTTTGC

Reverse primer $\left(5^{\prime}-3^{\prime}\right)$ GTGTGAGGAGGGTCATCGTT GTGTTCTGAGTTTCCGAAG TCAAAGCATCTTCCATGCAG GGTCCCATACGTCAGCTTGT CTTGGCCTGAGATTCTTTGC

\begin{tabular}{l} 
GenBank accession no. \\
\hline NM_001017960.1 \\
NM_012672.2 \\
NM_031347.1 \\
NM_001100708.1 \\
NM_031326.1 \\
NM_031559.2 \\
NM_013200.1 \\
NM_017340.2 \\
NM_031709.3
\end{tabular}

\begin{tabular}{c} 
Product size $(\mathrm{bp})$ \\
\hline 96 \\
90 \\
79 \\
97 \\
98 \\
82 \\
91 \\
75 \\
86
\end{tabular}

Thra, thyroid hormone receptor $\alpha$; Thrb, thyroid hormone receptor $\beta$; Ppargc1a, PPAR $\gamma$ coactivator-1 $\alpha$; Nrf1, nuclear respiratory factor $1 ;$ Tfam, mitochondrial transcription factor-A; Cpt1a, carnitine palmitoyltransferase-1A; Cpt1b, carnitine palmitoyltransferase-1B; Acox, acyl-CoA oxidase; Rps12, ribosomal protein S12.

http://joe.endocrinology-journals.org DOI: $10.1530 / J O E-13-0127$
(C) 2013 Society for Endocrinology Printed in Great Britain
Published by Bioscientifica Ltd 
cacodylate buffer containing $0.01 \mathrm{~g} / \mathrm{ml}$ osmium tetroxide. The samples were dehydrated with a graded ethanol series and later embedded in Epon 812 (Monteforte et al. 2009). Ultrathin sections, stained with $0.04 \mathrm{~g} / \mathrm{ml}$ uranyl acetate and subsequently with $0.01 \mathrm{~g} / \mathrm{ml}$ lead citrate, were examined using a Philips 301 transmission electron microscope (Philips Electronic Instruments, Rahway, NJ, USA).

Ultrastructural parameters (mitochondrial number per $100 \mu \mathrm{m}^{2}$, mitochondrial total area per $100 \mu \mathrm{m}^{2}$, and mitochondrial individual area) were measured on digitised electron micrographs using Image J Software (developed at the National Institutes of Health, Bethesda, MA, USA). Mitochondrial number per $100 \mu \mathrm{m}^{2}$ and mitochondrial total area per $100 \mu \mathrm{m}^{2}$ were measured in 20 different cells from each animal $(n=5)$ in each experimental group. Mitochondrial individual area was measured in a total of 1000 mitochondria from each experimental group.

\section{Western immunoblot analyses}

The peroxisomal sample protein concentrations were estimated using the method of Hartree (1972). Thirty micrograms of peroxisomal protein extracts were boiled in Laemmli buffer for $5 \mathrm{~min}$ and then separated on a 13\% SDS-PAGE gel. After electrophoresis, proteins were transferred onto a nitrocellulose membrane. The membrane was treated for $1 \mathrm{~h}$ with blocking solution (5\% non-fat powdered milk in $25 \mathrm{mM}$ Tris, pH 7.4; $200 \mathrm{mM} \mathrm{NaCl}$; $0.5 \%$ Triton X-100 and TBS/Tween 20) and then incubated with a mouse anti-human MAB against catalase (Sigma-Aldrich) diluted 1:3000, or a goat anti-mouse polyclonal antibody against uricase (Santa Cruz Biotechnology) diluted 1:1000, over night at $4{ }^{\circ} \mathrm{C}$. After washing with TBS/Tween, the membrane was incubated with the HRP-conjugated secondary antibody for $1 \mathrm{~h}$ at room temperature. The reactions were detected using an ECL system (Amersham Bioscience). Bands were scanned and then quantified by a Scan program, which converts optical density into numerical values. The protein levels of the uricase did not change in the various experimental groups. Therefore, catalase protein level data were normalised to uricase protein. Equal loading of the protein samples was confirmed by Ponceau staining.

\section{Statistical analyses}

ANOVA followed by a Student-Newman-Keuls's test was used to evaluate significant changes between experimental groups. Differences were considered statistically significant at $P<0.05$. All data were expressed as the mean \pm s.D.

\section{Results}

The combined effect of PTU and IOPA produced hypothyroid rats (hypo) with significantly lower $\mathrm{T}_{3}$ levels $(0.15 \pm 0.02 \mathrm{nmol} / \mathrm{l})$ than control rats $(0.89 \pm$ $0.07 \mathrm{nmol} / \mathrm{l}) ; \mathrm{T}_{3}$ administration to hypothyroid rats produced significantly higher $T_{3}$ levels $(1.91 \pm 0.09 \mathrm{nmol} / \mathrm{l})$.

\section{Thra and Thrb expression}

Thyroid receptors are members of the nuclear receptor superfamily and are derived from two genes located on two different chromosomes (Williams 2000). The Thrb gene encodes three $T_{3}$-binding TR $\beta$ isoforms ( $\beta 1, \beta 2$ and $\beta 3$ ) whereas the Thra gene encodes one $\mathrm{T}_{3}$-binding $\mathrm{TR} \alpha 1$ and two splicing variants (TR $\alpha 2$ and $T R \alpha 3$ ). These $T R \alpha$ variants have no $\mathrm{T}_{3}$-binding activity (Mitsuhashi et al. 1988). We found that both isoforms Thra1 and Thrb1 were expressed in rat HG; Thra1 mRNA levels were higher than Thrb1 levels, given the much lower normalised $C t$ values (Fig. 1). Thra1 mRNA levels were not influenced by the thyroid state (Fig. 1). Thrb1 mRNA levels of hypothyroid rats were significantly lower when compared with those of control rats (Fig. 1). A significant increase in Thrb1 expression compared with both the control and hypothyroid rats was observed in the HG of hypothyroid $\mathrm{T}_{3}$-treated rats (Fig. 1).

\section{Cpt1 and Acox gene expression}

To investigate the effects of $\mathrm{T}_{3}$ on $\mathrm{HG}$ fatty acid $\beta$-oxidation, the gene expression of both Cpt1 ( $a$ and $b$ ) and Acox was measured with real-time PCR. Both isoforms of Cpt1 ( $a$ and $b$ ) were expressed in rat HG; in particular, Cpt1a mRNA levels were not influenced by the thyroid

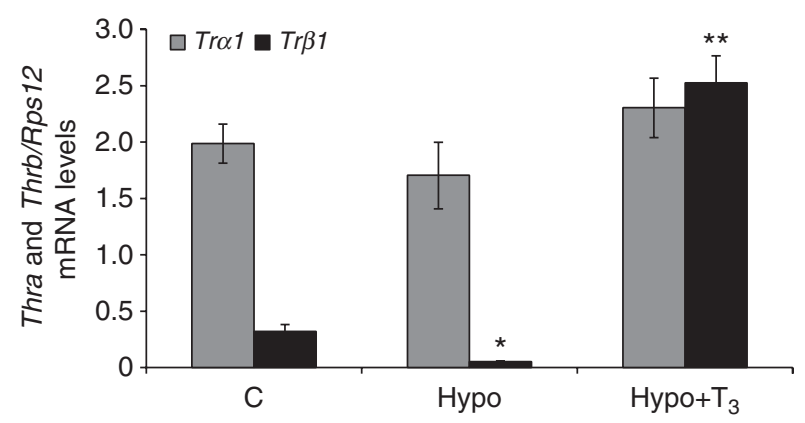

Figure 1

qRT-PCR analysis of Thra1 and Thrb1 mRNA in HG from control (C), hypothyroid (hypo) and hypothyroid $\mathrm{T}_{3}$-treated (hypo $+\mathrm{T}_{3}$ ) rats. The mRNA levels are normalised to ribosomal protein S12 (Rps12) mRNA levels. The values shown represent the means \pm s.D. for five samples. *, Thrb1 in hypo vs $\mathrm{C}_{;}{ }^{* *}$, Thrb1 in hypo $+\mathrm{T}_{3}$ vs $\mathrm{C}$ and hypo.

Published by Bioscientifica Ltd. 

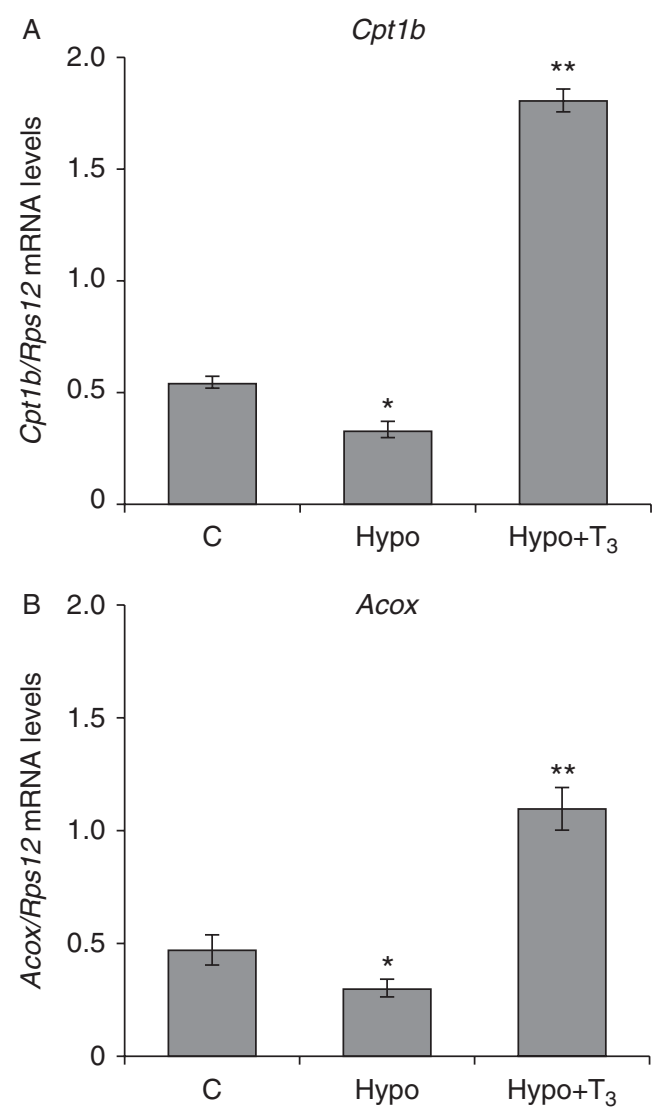

Figure 2

qRT-PCR analysis of Cpt1b and Acox from control (C), hypothyroid (hypo) and hypothyroid $\mathrm{T}_{3}$-treated (hypo $+\mathrm{T}_{3}$ ) rat HGs. The mRNA levels are normalised to the Rps12 mRNA levels. Values shown represent the means \pm s.D. for five samples. ${ }^{*}$, hypo vs $C ;{ }^{* *}$, hypo $+T_{3}$ vs $C$ and hypo.

state (data not shown). The Cpt1b mRNA levels of hypothyroid rats were significantly lower relative to those of control rats (Fig. 2). A significant increase in Cpt1b expression when compared with both control and hypothyroid rats was observed in the HG of hypothyroid $\mathrm{T}_{3}$-treated rats (Fig. 2).

The Acox mRNA level of hypothyroid rats was significantly lower relative to that of control rats (Fig. 2). A significant increase in Aox expression when compared with both control and hypothyroid rats was observed in the $\mathrm{HG}$ of hypothyroid $\mathrm{T}_{3}$-treated rats (Fig. 2).

\section{Respiratory parameters}

Mitochondrial respiratory rates are shown in Table 2 . With succinate used as a substrate, both state 4 and state 3 oxygen consumption were significantly lower in hypothyroid rats than in control ones (by 31 and 30\% respectively). $\mathrm{T}_{3}$ administration to hypothyroid rats induced a significant increase in both state 4 and state 3 oxygen consumption (by 25 and 21\% respectively). The respiratory control ratio values were not different between these groups.

\section{Mitochondrial ultrastructural and morphometric analyses}

We performed mitochondrial ultrastructural and morphometric analyses in type B cells of rat HG. B cells represent the initial stage of the secretory cycle of rat HG epithelium (Chieffi Baccari et al. 2004, Monteforte et al. 2008). These cells have a smaller number of secretory vacuoles and a larger number of mitochondria than type A cells, which represent the final stage of the secretory cycle. As shown in Fig. 3B, a larger number of mitochondria were present in hypothyroid $\mathrm{T}_{3}$-treated rat $\mathrm{HG}$ than in both the control (Fig. 3A) and hypothyroid rat HGs (not shown).

The morphometric data indicate that both the mitochondria number $\left(41 \pm 4 / 100 \mu \mathrm{m}^{2}\right)$ and the mean mitochondrial total area $\left(9 \pm 1 / 100 \mu \mathrm{m}^{2}\right)$ were significantly lower in hypothyroid than in control rats $(59 \pm 4$ and $12.1 \pm 1.5 / 100 \mu \mathrm{m}^{2}$ respectively) (Fig. 4). However, no significant differences in an average individual mitochondrial area were observed between hypothyroid HG (range, 0.022-0.946 $\mu \mathrm{m}^{2}$ ) and control HG (range, 0.016-1.13 $\mu^{2}$ ). In hypothyroid $\mathrm{T}_{3}$-treated rats, both the mitochondria number $\left(88 \pm 6 / 100 \mu \mathrm{m}^{2}\right)$ and the mean mitochondrial total area $\left(17.3 \pm 1.5 / 100 \mu \mathrm{m}^{2}\right)$ were significantly greater relative to those of both hypothyroid and control rats (Fig. 4). The average individual mitochondrial area (range, $0.021-0.537 \mu^{2}$ ) in the hypothyroid $T_{3}$-treated HG was about half of that found in the control HG.

\section{Expression of genes involved in mitochondrial biogenesis}

$P g c 1 \alpha, N r f 1$ and Tfam mRNA levels did not change in hypothyroid rats when compared with the controls (Fig. 5).

Table 2 Respiratory parameters in the HG of control (C), hypothyroid (hypo) and hypothyroid $\mathrm{T}_{3}$-treated (hypo $+\mathrm{T}_{3}$ ) rats. The values for states 4 and 3 respiration are expressed as nanoatoms of oxygen consumption per minute per milligram of protein. Results are expressed as the mean \pm s.D. from five experiments in each group

\begin{tabular}{|c|c|c|c|}
\hline Animals & State 4 & State 3 & RCR \\
\hline C & $6.2 \pm 0.7$ & $25.1 \pm 1.6$ & $4.0 \pm 0.3$ \\
\hline Нуро & $4.3 \pm 0.3 *$ & $17.7 \pm 1.1 *$ & $4.1 \pm 0.3$ \\
\hline Нуро $+\mathrm{T}_{3}$ & $7.8 \pm 0.2 *$ & $30.4 \pm 1.9 *$ & $3.9 \pm 0.1$ \\
\hline
\end{tabular}

RCR, respiratory control ratio (state 3 over state 4$) .{ }^{*} P<0.05$.

Published by Bioscientifica Ltd. 


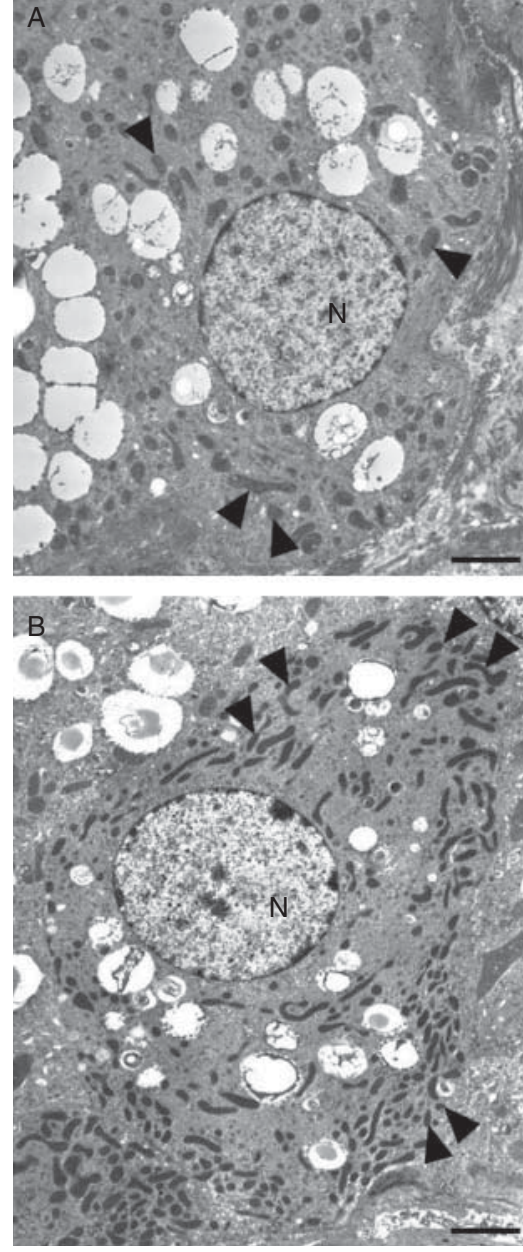

Figure 3

Electron micrographs of type $B$ cells from rat HG. (A) Type B from control rat HG is characterised by cytoplasmic unstained vacuoles and a moderate number of mitochondria (arrowheads). (B) Numerous mitochondria (arrowheads) and some secretory vacuoles are present in type B cell of hypothyroid $\mathrm{T}_{3}$-treated rat HG. N, nucleus. Scale bar, $2 \mu \mathrm{m}$.

$\mathrm{T}_{3}$ administration to hypothyroid rats induced a significant increase in Ppargc1a, Nrf1 and Tfam expression (Fig. 5).

\section{Catalase protein expression}

Catalase protein level in hypothyroid rats was significantly lower compared with control rats (Fig. 6). A significant increase in catalase protein expression when compared with hypothyroid rats was observed in the HG of hypothyroid $\mathrm{T}_{3}$-treated rats (Fig. 6).

\section{Discussion}

To our knowledge, this report is the first describing the expression and regulation of $\mathrm{TH}$ receptors in the rat HG.
Results indicated that both Thra and Thrb are present in rat HG, with levels of Thra being the highest. It is well known that Thra and Thrb mRNAs are expressed in most rat tissues, although their relative abundance varies (Cheng et al. 2010 for review). For example Thra1 is the major isoform expressed in the heart (Falcone et al. 1992, Mai et al. 2004), whereas Thrb1 predominates in the liver (Harvey \& Williams 2002). In the brain, Thra1 is the major foetal isoform, but at birth, there is a marked increase in the expression of Thrb1, which is later maintained during adult life (Harvey \& Williams 2002). It is well known that the regulation of TH receptor mRNA is isoform- and cell-type dependent (Cheng et al. 2010, Flamant \& Gauthier 2013 for reviews). We found that, although higher levels of Thra1 are present in the rat HGs, only Thrb1 is regulated by $\mathrm{T}_{3}$. Experimentally induced hypothyroidism decreased HG Thrb1 mRNA expression, whereas the administration of $\mathrm{T}_{3}$ increased Thrb1 transcript levels.

As it has been reported that the HG could play a role in thermoregulation and its activity is influenced by temperature (Chieffi et al. 1996 for review), we carried out the experiments under conditions of thermoneutrality, about $28^{\circ} \mathrm{C}$ for rats. It is well known that an ambient temperature of $21^{\circ} \mathrm{C}$ represents a mild cold stress to an individually housed rat (Brown et al. 1991). Indeed, total heat production over $24 \mathrm{~h}$ was $\sim 25 \%$ higher for rats at 21 than $28^{\circ} \mathrm{C}$ and underlying thermogenesis was $\sim 20 \%$ higher for those in mild cold (Golozoubova et al. 2004, Feldmann et al. 2009).

In previous studies, we demonstrated that hypothyroidism provoked a reduction in lipid secretion in rat HG (Monteforte et al. 2008), whereas $\mathrm{T}_{3}$ administration increased gland secretion with the accumulation of products in the lumina (Chieffi Baccari et al. 2004). In this study, we decided to investigate the effects of thyroid status on expression levels of Cpt1 and Acox, which are

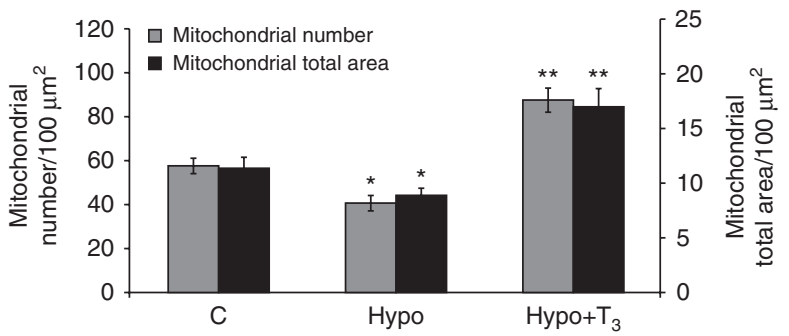

Figure 4

Both mitochondrial number and total area are significantly lower in hypothyroid (hypo) and higher in hypothyroid $\mathrm{T}_{3}$-treated (hypo $+\mathrm{T}_{3}$ ) rat HG compared with control (C). *, hypo vs $C ;{ }^{* *}$, hypo $+T_{3}$ vs $C$ and hypo. 

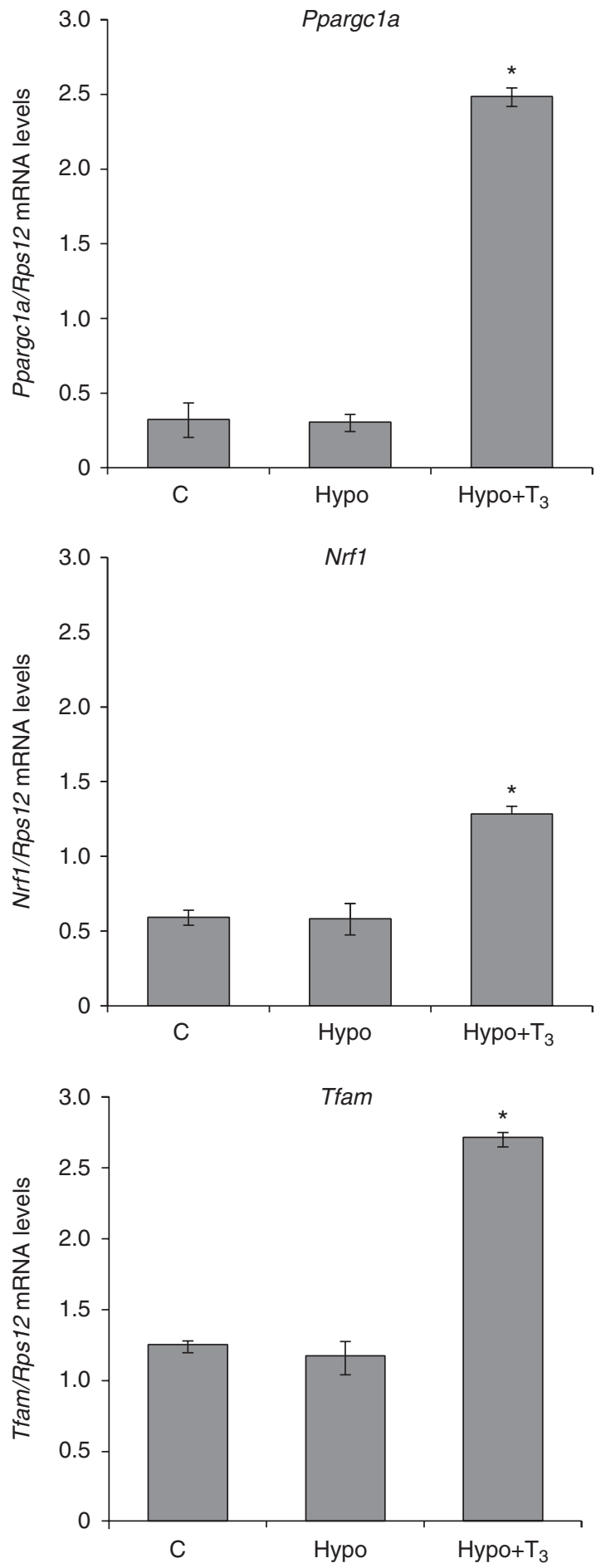

Figure 5

qRT-PCR analysis of genes involved in mitochondrial biogenesis from control (C), hypothyroid (hypo) and hypothyroid $\mathrm{T}_{3}$-treated (hypo $+\mathrm{T}_{3}$ ) rat $\mathrm{HGs}$. The mRNA levels are normalised to the Rps12 mRNA levels. Values shown represent the means \pm s.D. for five samples. ${ }^{*}$, hypo $+T_{3}$ vs $C$ and hypo. rate-limiting enzymes in mitochondrial and peroxisomal fatty acid oxidation respectively. In particular, CPT1 catalyses the transfer of long-chain fatty acyl groups from CoA to carnitine for translocation across the mitochondrial inner membrane (see Bonnefont et al. 2004 for review), whereas AOX is the first enzyme of peroxisomal fatty acid $\beta$-oxidation, which catalyses the dehydrogenation of acyl-CoA thioesters to the corresponding trans-2-enoyl-CoA (Reddy \& Mannaerts 1994). It has been demonstrated that $\mathrm{TH}$ induced an increase in $C p t 1 b$ mRNA levels in adipocytes (Lee et al. 2012), whereas TH induced Cpt1a in the liver, the predominant isoform in this tissue (Zhu \& Cheng 2010). In this study, we demonstrated that both isoforms Cpt1a and Cpt1b were expressed in rat HG and that thyroid status did not affect the Cpt1a expression. On the contrary, $C p t 1 b$ transcripts significantly decreased in hypothyroid $\mathrm{HG}$ and increased following $\mathrm{T}_{3}$ treatment. Furthermore, we found that the expression of Aox was strongly up-regulated by $\mathrm{T}_{3}$, suggesting an involvement of peroxisomes in lipid catabolism in the rat HG. Peroxisomes mainly act in the $\beta$-oxidation of
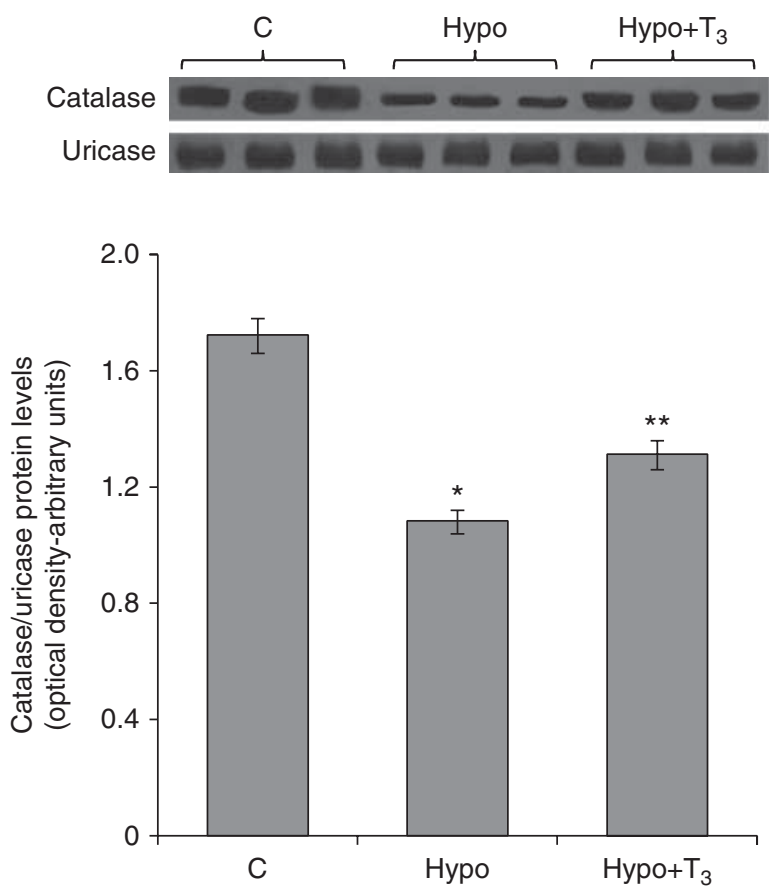

Figure 6

The upper panel shows western blot detection of catalase protein in HG from control, hypothyroid (hypo) and hypothyroid $\mathrm{T}_{3}$-treated (hypo $+\mathrm{T}_{3}$ ) rat HGs. A specific band was observed at a size of $60 \mathrm{kDa}$. The lower panel shows the amount of catalase protein quantified using the Image J Program and normalised with respect to uricase (see upper panel). Values shown represent the means \pm s.D. of five samples. *, hypo vs $C_{\text {; }}$ $* *$, hypo $+\mathrm{T}_{3}$ vs hypo.

Published by Bioscientifica Ltd. 
very-long-chain fatty acids. Rat HG routinely secretes very long-chain fatty acids, saturated fatty acids up to C30 and even monoenoic acids up to C28 (Tvrzickà et al. 1988, Seyama et al. 1992). Unlike in mitochondrial $\beta$-oxidation, fatty acid degradation in peroxisomes is accompanied by $\mathrm{H}_{2} \mathrm{O}_{2}$ production (Reddy \& Mannaerts 1994). The involvement of the peroxisomes in rat HG lipid oxidation is supported by different activity, which these organelles showed in the experimental groups. In particular, we found that catalase expression decreased in hypothyroid rat $\mathrm{HG}$ and increased following $\mathrm{T}_{3}$ treatment.

It is well documented that TH stimulate fat oxidation, mainly by acting at mitochondrial levels. Therefore, we thought it interesting to assess mitochondrial activity by studying respiratory parameters. We found that both state 4 and 3 of respiration were decreased in hypothyroid rats and increased after $T_{3}$ administration. This could be consistent with either increased activity or an increased number of mitochondria. The morphometric analysis revealed that the mitochondrial number and their total area significantly decreased in hypothyroid rat HG when compared with the controls, whereas the average area of individual mitochondria did not change. In keeping with these findings, autophagic degradation of mitochondria was the most notable effect caused by hypothyroidism in rat HG (Monteforte et al. 2008). Although the average area of the individual mitochondrion was reduced by $\sim 50 \%$ in hypothyroid $\mathrm{T}_{3}$-treated $\mathrm{HG}$, the mitochondrial number and the total area of the mitochondrial compartment significantly increased. This result could be ascribed to an increased number of smaller mitochondrial due to division of pre-existing mitochondria. Proliferation of mitochondria in rat liver (with an increased number of smaller mitochondria) after $\mathrm{T}_{3}$ administration has been previously reported by Goglia et al. (1985). The present mitochondrial morphological and morphometric data correlated well with the molecular results. Indeed, we demonstrated that Pprgc1a, Nrf1 and Tfam mRNA expression was induced by $\mathrm{T}_{3}$ treatment. PPARGC1 $\alpha$, which is predominantly expressed in brown adipose tissue and skeletal muscle, is currently considered to be the most important regulator of mitochondrial biogenesis (Puigserver \& Spiegelman 2003) and activates the production of NRF1 and NRF2. These two factors, of which NRF1 is the most important, are potent stimulators of the expression of TFAM, which is a potent stimulator of mitochondrial DNA duplication (Puigserver et al. 1998). Thus, when active mitochondriogenesis is required, i.e. due to increased lipid excretion, PPARGC1 $\alpha$ is activated, leading to NRF1 activation and a subsequent increase in TFAM synthesis, as well as mitochondria duplication. However, it has been demonstrated that $T_{3}$ has profound effects on mitochondrial biogenesis by modulating the expression of several mitochondrial respiratory genes (Sheehan et al. 2004).

Therefore, this study demonstrated that, in rat HG, $\mathrm{T}_{3}$ affects mitochondrial and peroxisomal fat oxidation as well as mitochondrial biogenesis through Thrb1. Further studies will clarify whether the effects of $\mathrm{T}_{3}$ on rat $\mathrm{HG}$ were a direct and/or indirect consequence of fatty acid overload.

\section{Declaration of interest}

The authors declare that there is no conflict of interest that could be perceived as prejudicing the impartiality of the research reported.

\section{Funding}

This research did not receive any specific grant from any funding agency in the public, commercial or not-for-profit sector.

\section{References}

Bonnefont JP, Djouadi F, Prip-Buus C, Gobin S, Munnich A \& Bastin J 2004 Carnitine palmitoyltransferases 1 and 2: biochemical, molecular and medical aspects. Molecular Aspects of Medicine 25 495-520. (doi:10.1016/ j.mam.2004.06.004)

Brown D, Livesey G \& Dauncey MJ 1991 Influence of mild cold on the components of 24 hour thermogenesis in rats. Journal of Physiology $\mathbf{4 4 1}$ 137-154.

Buzzell GR \& Menendez-Pelaez A 1992 The interrelationship between the Harderian glands and the neuroendocrine-thyroid axis in rodents. In Harderian Glands: Porphyrin Metabolism, Behavior and Endocrine Effects, pp 255-270. Eds SM Webb, RA Hoffman, ML Puig-Domingo \& RJ Reiter. Berlin: Springer-Verlag.

Buzzell GR, Menendez-Pelaez A, Hoffman RA, Rodriguez C \& Antolin I 1994 Androgenic control of porphyrin in the Harderian glands of the male Syrian hamster is modulated by photoperiod, which suggest that the sexual differences in porphyrin concentrations in this gland are important functionally. Anatomical Record 240 52-58. (doi:10.1002/ ar.1092400106)

Cheng SY, Leonard JL \& Davis PJ 2010 Molecular aspects of thyroid hormone actions. Endocrine Reviews 31 139-170. (doi:10.1210/ er.2009-0007)

Chieffi G, Chieffi Baccari G, Di Matteo L, d'Istria M, Minucci S \& Varriale B 1996 Cell biology of the Harderian gland. International Review of Cytology 168 1-80.

Chieffi Baccari G, Di Matteo L, d'Istria M, Minucci S, Serino I \& Varriale B 1993 The effects of gonadectomy and testosterone treatment on the Harderian gland of the green frog, Rana esculenta. Cell and Tissue Research 273 201-208. (doi:10.1007/BF00312821)

Chieffi Baccari G, Monteforte R, de Lange P, Raucci F, Farina P \& Lanni A 2004 Thyroid hormone affects secretory activity and uncoupling protein-3 expression in rat Harderian gland. Endocrinology 145 3338-3345. (doi:10.1210/en.2004-0060)

Cioffi F, Senese R, de Lange P, Goglia F, Lanni A \& Lombardi A 2009 Uncoupling proteins: a complex journey to function discovery. Biofactors 35 417-428. (doi:10.1002/biof.54)

Coto-Montes A, Tomás-Zapico C, Martínez-Fraga J, Vega-Naredo I, Sierra V, Caballero B, Huidobro-Fernández C, Soria-Valles C, Tolivia D \& Rodríguez-Colunga MJ 2009 Sexual autophagic differences in the 
androgen-dependent flank organ of Syrian hamsters. Journal of Andrology 30 113-121. (doi:10.2164/jandrol.108.005355)

Delgado MJ, Guerrero JM, Santana C, Menendez-Pelaez A, Gonzalez-Brito A, Chen ZL \& Reiter RJ 1988 Thyroxine 5'-deiodinase activity in brown adipose tissue, Harderian gland, pineal gland and pituitary gland of the male Syrian hamster (Mesocricetus auratus). Neuro Endocrinology Letters 10 363-368.

Estabrook RW 1967 Mitochondrial respiratory control and the polarographic measurement of ADP:O ratio. Methods in Enzymology 10 41-47. (doi:10.1016/0076-6879(67)10010-4)

Falcone M, Miyamoto T, Fierro-Renoy F, Macchia E \& DeGroot LJ 1992 Antipeptide polyclonal antibodies specifically recognize each human thyroid hormone receptor isoform. Endocrinology $1312419-24129$. (doi:10.1210/en.131.5.2419)

Feldmann HM, Golozoubova V, Cannon B \& Nedergaard J 2009 UCP1 ablation induces obesity and abolishes diet-induced thermogenesis in mice exempt from thermal stress by living at thermoneutrality. Cell Metabolism 9 203-209. (doi:10.1016/j.cmet.2008.12.014)

Flamant F \& Gauthier K 2013 Thyroid hormone receptors: the challenge of elucidating isotype-specific functions and cell-specific response. Biochimica et Biophysica Acta 1830 3900-3907. (doi:10.1016/j.bbagen. 2012.06.003)

Goglia F, Liverini G, Lanni A, Bottiglieri S \& Barletta A 1985 Alteration in hepatic mitochondrial compartment of cold acclimated rats. Experimental Biology 44 41-56.

Golozoubova V, Gullberg H, Matthias A, Cannon B, Vennström B \& Nedergaard J 2004 Depressed thermogenesis but competent brown adipose tissue recruitment in mice devoid of all hormone-binding thyroid hormone receptors. Molecular Endocrinology 18 384-401. (doi:10.1210/me.2003-0267)

Guerrero JM, Puig-Domingo M, Vaughan GM \& Reiter RJ 1987 Characterization of type-II thyroxine $5^{\prime}$-deiodinase activity in rat Harderian gland. Life Sciences 41 1179-1185. (doi:10.1016/ 0024-3205(87)90638-2)

Hartree EF 1972 Determination of protein: a modification of the Lowry method that gives a linear photometric response. Analytical Biochemistry 48 422-427. (doi:10.1016/0003-2697(72)90094-2)

Harvey CB \& Williams GR 2002 Mechanism of thyroid hormone action. Thyroid 12 441-446. (doi:10.1089/105072502760143791)

Hoffman RA, Wertz P \& Habeeb P 1989 Harderian glands of golden hamsters: morphological and biochemical responses to thyroid hormones. Journal of Comparative Physiology. B, Biochemical, Systemic, and Environmental Physiology 159 293-299. (doi:10.1007/BF00691508)

d'Istria M, Chieffi Baccari G, Di Matteo L, Minucci S, Varriale B \& Chieffi G 1991 Androgen receptor in the Harderian gland of Rana esculenta. Journal of Endocrinology 129 227-232. (doi:10.1677/joe.0.1290227)

Kaplan MM \& Utiger RD 1978 Iodothyronine metabolism in rat liver homogenates. Journal of Clinical Investigation 61 459-471. (doi:10.1172/JCI108957)

Lanni A, Moreno M, Lombardi A \& Goglia F 1996 Calorigenic effect of diiodothyronines in the rat. Journal of Physiology 494 831-837.

Lee JY, Takahashi N, Yasubuchi M, Kim YI, Hashizaki H, Kim MJ, Sakamoto T, Goto T \& Kawada T 2012 Triiodothyronine induces UCP-1 expression and mitochondrial biogenesis in human adipocytes. American Journal of Physiology. Cell Physiology 302 463-472. (doi:10.1152/ajpcell.00010.2011)

Leonard JL \& Visser TJ 1986 Biochemistry of deiodination. In Thyroid Hormone Metabolism, pp 189-229. Ed. G Hennemann. New York: Marcel Dekker, Inc.

Lin WL \& Nadakavukaren MJ 1981 Harderian gland lipids of male and female golden hamster. Comparative Biochemistry and Physiology 70 627-630. (doi:10.1016/0300-9629(81)92590-1)

Mai W, Janier MF, Allioli N, Quignodon L, Chuzel T, Flamant F \& Samarut J 2004 Thyroid hormone receptor $\alpha$ is a molecular switch of cardiac function between fetal and postnatal life. PNAS 101 10332-10337. (doi:10.1073/pnas.0401843101)
McMasters KM \& Hoffman RA 1984 Harderian gland: regulation of sexual "type" by gonads and pineal gland. Biology of Reproduction 31 579-585. (doi:10.1095/biolreprod31.3.579)

Minucci S, Chieffi Baccari G, Di Matteo L, Marmorino C, d'Istria M \& Chieffi G 1990 Influence of light and temperature on the secretory activity of the Harderian gland of the green frog, Rana esculenta. Comparative Biochemistry and Physiology. Part A, Comparative Physiology 95 249-252. (doi:10.1016/0300-9629(90)90206-8)

Mitsuhashi T, Tennyson GE \& Nikodem VM 1988 Alternative splicing generates messages encoding rat c-erbA proteins that do not bind thyroid hormone. PNAS $\mathbf{8 5} 5804-5808$. (doi:10.1073/pnas.85.16.5804)

Monteforte R, Santillo A, Lanni A, D’Aniello S \& Chieffi Baccari G 2008 Morphological and biochemical changes in the Harderian gland of hypothyroid rats. Journal of Experimental Biology 211 606-612. (doi:10.1242/jeb.015115)

Monteforte R, Santillo A, Di Giovanni M, D'Aniello A, Di Maro A \& Chieffi Baccari G 2009 D-aspartate affects secretory activity in rat Harderian gland: molecular mechanism and functional significance. Amino Acids 37 653-664. (doi:10.1007/s00726-008-0185-8)

Oppenheimer JH, Schwartz HL \& Surks MI 1972 Propylthiouracil inhibits the conversion of L-thyroxine to L-triiodothyronine. Journal of Clinical Investigation 51 2493-2497. (doi:10.1172/JCI107063)

Osuna C, Rubio A, Goberna R \& Guerrero JM 1990 Ontogeny of type II thyroxine $5^{\prime}$-deiodinase, $\mathrm{N}$-acetyltransferase, and hydroxyindole$O$-methyltransferase activities in the rat Harderian gland. Life Sciences 46 1945-1951. (doi:10.1016/0024-3205(90)90510-X)

Puigserver P \& Spiegelman BM 2003 Peroxisome proliferator-activated receptor-gamma coactivator $1 \alpha$ (PGC-1 $\alpha$ ): transcriptional coactivator and metabolic regulator. Endocrine Reviews 24 78-90. (doi:10.1210/er. 2002-0012)

Puigserver P, Wu Z, Park CW, Graves R, Wright M \& Spiegelman BM 1998 A cold-inducible coactivator of nuclear receptors linked to adaptive thermogenesis. Cell 92 829-839. (doi:10.1016/S0092-8674(00)81410-5)

Reddy JK \& Mannaerts GP 1994 Peroxisomal lipid metabolism. Annual Review of Nutrition 14 343-370. (doi:10.1146/annurev.nu.14.070194. 002015)

Sakai T 1981 The mammalian Harderian gland: morphology, biochemistry, function and phylogeny. Archivum Histologicum Japonicum = Nippon Soshikigaku Kiroku 44 299-333. (doi:10.1679/ aohc1950.44.299)

Santillo A, Monteforte R, De Lange P, Lanni A, Farina P \& Chieffi Baccari G 2008 Dimorphic expression of uncoupling protein-3 in golden hamster Harderian gland: effects of castration and testosterone administration. Journal of Cellular Physiology 215 481-487. (doi:10.1002/jcp.21333)

Santillo A, Burrone L, Minucci S, Di Giovanni M \& Chieffi Baccari G $2011 a$ Molecular pathways involved in the cyclic activity of frog (Pelophylax esculentus) Harderian gland: influence of temperature and testosterone. Comparative Biochemistry and Physiology. Part B, Biochemistry \& Molecular Biology 158 71-76. (doi:10.1016/j.cbpb.2010.09.007)

Santillo A, Burrone L, Senese R, Cioffi F, Lanni A \& Chieffi Baccari G $2011 b$ Effect of D-aspartate uptake on uncoupling protein-3 and $\alpha$-tubulin expressions in rat Harderian gland. Journal of Chromatography. B, Analytical Technologies in the Biomedical and Life Sciences 879 3344-3348. (doi:10.1016/j.jchromb.2011.04.001)

Seyama Y, Kasama T, Yasugi E, Park SH \& Kano K 1992 Lipids in Harderian glands and their significance. In Harderian Glands: Porphyrin Metabolism, Behavior and Endocrine Effects, pp 195-217. Eds SM Webb, RA Hoffman, ML Puig-Domingo \& RJ Reiter. Berlin: Springer-Verlag.

Shanas U \& Terkel J 1996 Grooming secretions and seasonal adaptations in the blind mole rat (Spalax ehrenbergi). Physiology \& Behavior 60 653-656. (doi:10.1016/S0031-9384(96)80044-REF47=10.1111/j.1749-6632.1988. tb38593.x)

Sheehan TE, Kumar PA \& Hood DA 2004 Tissue-specific regulation of cytochrome $c$ oxidase 504 subunit expression by thyroid hormone. 
American Journal of Physiology. Endocrinology and Metabolism 286 E968-E974. (doi:10REF49=10.1677/joe.0.1120003)

St Germain DL 1994 Biochemical study of type III iodothyronine deiodinase. In Thyroid Hormone Metabolism, Molecular Biology and Alternative Pathways, pp 45-66. Eds SY Wu \& TJ Visser. Boca Raton: CRC Press, Inc.

Thiessen DD 1988 Body temperature and grooming in the Mongolian gerbil. Annals of the New York Academy of Sciences 525 27-39. (doi:10.1111/j.1749-6632.1988.tb38593.xREF51=10.1097/MED. 0b013e32833d6d46)

Tvrzická E, Rezanka T, Krijt J \& Janousek V 1988 Identification of very-long-chain fatty acids in rat and mouse Harderian gland lipids by capillary gas chromatography-mass spectrometry. Journal of Chromatography 431 231-238.

Vilchis F \& Pérez-Palacios G 1989 Steroid hormone receptors and the sexual phenotype of the Harderian gland in hamster. Journal of Endocrinology 112 3-8. (doi:10.1677/joe.0.1120003)

Williams GR 2000 Cloning and characterization of two novel thyroid hormone receptor $\beta$ isoforms. Molecular and Cellular Biology 20 8329-8342. (doi:10.1128/MCB.20.22.8329-8342.2000)

Zhu X \& Cheng S 2010 New insights into regulation of lipid metabolism by thyroid hormone. Current Opinion in Endocrinology, Diabetes and Obesity 17 408-413. (doi:10.1097/MED.0b013e32833d6d46)

Received in final form 9 July 2013

Accepted 19 July 2013

Accepted Preprint published online 19 July 2013 http://joe.endocrinology-journals.org DOI: 10.1530/JOE-13-0127
() 2013 Society for Endocrinology Printed in Great Britain
Published by Bioscientifica Ltd. 